\title{
Analisis pengaruh anomali iklim terhadap curah hujan di Propinsi Bengkulu
}

\author{
Muhammad Rizky Ismaila, Ahmad Zakaria ${ }^{\mathrm{b},{ }^{*},}$, Gatot Eko Susiloc \\ a Mahasiswa Magister Teknik Sipil, Universitas Lampung, Jl. Soemantri Brojonegoro No. 1 Bandar Lampung, 35145, Indonesia \\ ${ }^{b}$ Jurusan Teknik Sipil, Universitas Lampung, Jl. Soemantri Brojonegoro No. 1 Bandar Lampung, 35145, Indonesia \\ ${ }^{c} J u r u s a n$ Teknik Sipil, Universitas Lampung, Jl. Soemantri Brojonegoro No. 1 Bandar Lampung, 35145, Indonesia
}

\section{H I G H L I G H T S}

- Metode fast fourier transform dan lomb periodogram serta sumber data BMKG dan TRMM digunakan untuk melihat pengaruh anomali iklim di Propinsi Bengkulu.

- Dari data yang bersumber dari BMKG dan TRMM, beberapa daerah di Bengkulu dipengaruhi oleh IODM.

- Kecenderungan pertumbuhan pengaruh IODM di daerah Bengkulu umumnya mempunyai kecenderungan naik.

\section{N F O A R T I K E L}

\section{Riwayat artikel:}

Diterima 15 Desember 2019

Diterima setelah diperbaiki 05 Januari 2020

Diterima untuk diterbitkan 10 Februari 2020

Tersedia secara online 12 Maret 2020

\section{Kata kunci:}

Anomali iklim,

metode fast fourier transform,

metode lomb priodogram.

\begin{abstract}
A B S T R A K
Propinsi Bengkulu adalah salah satu daerah di Indonesia yang dipengaruhi oleh anomali iklim, diantaranya adalah bencana banjir dan kekeringan. Dengan demikian, diperlukan penelitian untuk mengetahui pengaruh anomali iklim terhadap curah hujan di Propinsi Bengkulu. Tujuan penelitian ini adalah untuk mengetahui: daerah yang dominan terpengaruh oleh anomali iklim, perulangan anomali iklim dan kecendrungan pertumbuhan anomali iklim di Propinsi Bengkulu. Metode yang digunakan adalah metode fast fourier transform (FFT) dan lomb periodogram. Hasil penelitian menunjukkan periode frekuensi dominan adalah perulangan 2,8 tahun untuk FFT, sedangkan lomb periodogram adalah 3,8 - 4,4 tahun. Hasil analisis FFT menunjukkan nilai amplitudo dari data BMKG adalah 1,2 $\mathrm{mm}^{2}-3,4 \mathrm{~mm}^{2}$, sedangkan dari data TRMM nilai amplitudo adalah $0,1 \mathrm{~mm}^{2}-$ $0,6 \mathrm{~mm}^{2}$. Dengan menggunakan metode lomb periodogram didapatkan nilai amplitudo $2,5 \mathrm{~mm}^{2}-25 \mathrm{~mm}^{2}$ dari data BMKG dan dari data TRMM diperoleh amplitude sebesar $0,28 \mathrm{~mm}^{2}-0,37 \mathrm{~mm}^{2}$. Kesimpulan dari hasil penelitian ini adalah anomali iklim yang berpengaruh menurut hasil FFT adalah IODM dengan perulangan 2,8 tahun, sedangkan dari lomb periodogram yang berpengaruh adalah ENSO dengan perulangan 3,8 - 4,4 tahun. Disimpulkan pula bahwa daerah dominan terpengaruh oleh anomali iklim menurut data BMKG adalah Kepahiyang, sedangkan untuk TRMM adalah daerah Fatmawati dan Pulau Baai. Untuk kecenderungan pertumbuhan pengaruh anomali iklim, bahwa setiap stasiun kecuali Fatmawati BMKG, punya kecendrungan naik.
\end{abstract}

Diterbitkan oleh Jurusan Teknik Sipil Universitas Lampung

\section{Pendahuluan}

Indonesia adalah salah satu negara tropis yang terdampak oleh anomali iklim. Dari banyak bencana alam yang terjadi di Indonesia, 95\% terjadi dikarenakan perubahan iklim. Berada di daerah tropis juga menjadikan Indonesia salah satu negara yang terpengaruh oleh bebe-

\footnotetext{
* Penulis koresponden.

Alamat e-mail: ahmad.zakaria@eng.unila.ac.id (A. Zakaria). Peer review dibawah tanggung-jawab Jurusan Teknik Sipil Universitas Lampung.

https://doi.org/10.23960/rekrjits.v24i1.11
}

rapa fenomena alam. Fenomena ini memberikan pengaruh yang sangat besar dalam banyak hal, terutama yang mempengaruhi tinggi atau rendahnya curah hujan [1]. Selain itu, fenomena alam ini juga menjadi akar permasalahan dari $50 \%$ konflik sipil yang terjadi di negara tropis [2]. Dalam empat dekade terakhir, pengaruh dari fenomena alam menjadi salah satu hal yang mendominasi.

Saat terjadinya El Nino, suhu permukaan air laut di Pasifik bagian timur akan naik. Kejadian ini bisa dilihat secara kasat mata di daerah Ekuador dan Peru. Ada beberapa tahapan terjadinya El Nino. Pertama adalah naiknya suhu di bagian tengah dan timur perairan Pasifik, setelah itu yang kedua adalah pembentukan awan yang terjadi di daerah tersebut dan yang ketiga adalah terham- 
batnya pembentukan awan di daerah barat Samudera Pasifik dikarenakan tekanan udara yang meningkat.

La Nina adalah keadaan alam yang berbanding terbalik dengan El Nino. La Nina secara etimologi diartikan anak perempuan. Kejadian La Nina adalah turunnya suhu di daerah Samudera Pasifik dan sekitar daerah Ekuador. Berbeda dengan El Nino yang dapat dilihat tandanya secara fisik, La Nina tidak dapat dilihat secara fisik sehingga sulit untuk memperkirakan terjadinya La Nina. Pengaruh yang ditimbulkan La Nina juga mempengaruhi daerah di Indonesia. Beberapa pengaruh akibat terjadinya La Nina adalah naiknya potensi hujan dan juga naiknya tinggi curah hujan di berbagai daerah di Indonesia dan sekitarnya

Indian - Ocean Dipole Mode (IODM) adalah salah satu fenomena alam yang berpengaruh di Indonesia. Dipole Mode adalah perubahan yang terjadi di Samudera Hindia dan beberapa bagian di Sumatera. Fenomena ini disebabkan oleh perbedaan anomali suhu di Pantai Timur Afrika dan Pantai Barat Sumatera. Indian Ocean Dipole Mode dinilai lebih berpengaruh terhadap Bagian Barat Indonesia, sehingga menjadi penting untuk mengetahui pengaruh yang terjadi di Indonesia.

Dalam memperhitungkan pengaruh yang diakibatkan anomali iklim, ada beberapa metode yang dapat digunakan, diantaranya adalah metode fast fourier transform (FFT) dan metode lomb periodogram. Metode ini secara khusus dapat mengetahui peningkatan dan penurunan yang terjadi pada curah hujan yang menghasilkan bentuk spektrum hujan yang dihasilkan dari data curah hujan yang didapat [3], sehingga didalam penelitian ini memfokuskan pada perbandingan data puncak spektrum hasil dari analisis dengan dua metode yang berbeda.

Dalam merencanakan mitigasi bencana dan juga pengendalian banjir, seringkali perencanaan tidak sesuai dengan keadaan yang terjadi. Sehingga diperlukan analisis untuk menentukan daerah mana yang lebih terdampak fenomena anomali iklim. Didalam banyak aspek kehidupan seringkali terpengaruh oleh fenomena anomali iklim sehingga diperlukannya referensi dalam mengetahui perulangan dan kecendrungan pertumbuhan dari fenomena anomali iklim yang terjadi.

Tujuan Penelitian ini adalah untuk menganalisis perulangan dari pengaruh anomali iklim terhadap curah hujan di Propinsi Bengkulu, mengetahui daerah yang dominan terpengaruh oleh anomali iklim dan menganalisis kecenderungan pertumbuhan pengaruh dari anomali iklim yang terjadi.

\section{Metode Penelitian}

Wilayah yang menjadi batasan untuk penelitian ini adalah di Propinsi Bengkulu, yang berbatasan dengan beberapa daerah yaitu di daerah utara berbatasan dengan Propinsi Sumatera Barat, di daerah selatan berbatasan dengan Propinsi Lampung, di daerah timur berbatasan dengan Propinsi Jambi dan Sumatera Selatan dan di daerah barat berbatasan dengan Samudera Hindia. Propinsi Bengkulu dinilai memiliki keadaan alam yang beragam dan dapat terpengaruh langsung oleh fenomena anomali alam dikarenakan berbatasan langsung dengan Samudera Hindia. Berikut Gambar 1 adalah peta lokasi Propinsi Bengkulu.

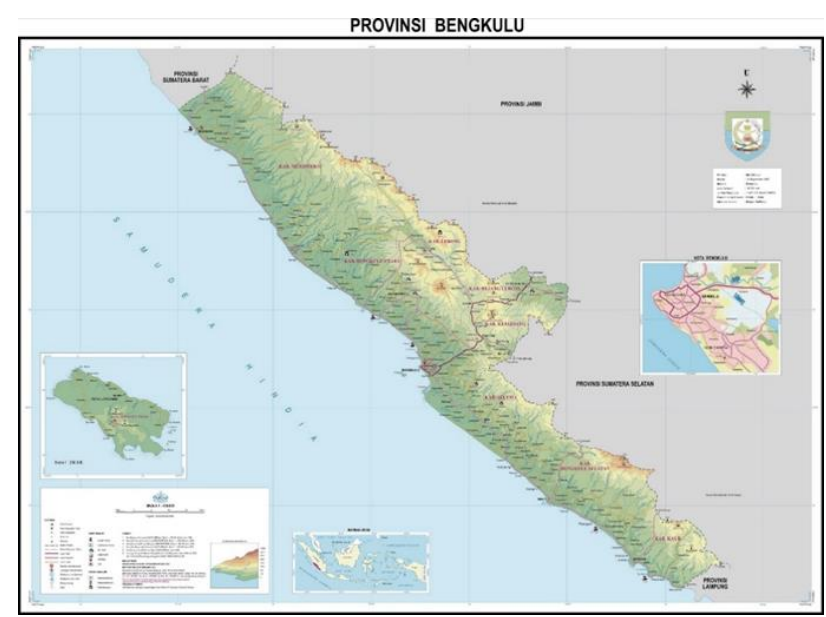

Gambar 1 Peta wilayah Provinsi Bengkulu

Data yang digunakan dalam penelitian ini adalah data curah hujan di Propinsi Bengkulu, terdiri dari tiga stasiun hujan, yaitu stasiun Fatmawati Soekarno, stasiun Kepahiyang dan stasiun Klimatologi Bengkulu atau Pulau Baai. Data curah hujan yang digunakan juga memiliki perbedaan, yaitu data ground dan data $250 \mathrm{~m}$ di atas permukaan tanah. Data diperoleh dari sumber Badan Meteorologi, Klimatologi dan Geofisika (BMKG) untuk data ground dan dari satelit tropical rainfall measuring mission (TRMM) untuk data $250 \mathrm{~m}$ di atas permukaan tanah. Untuk kurun waktu, data yang digunakan adalah 20 tahun, yaitu dari tahun 1998 sampai dengan 2018. Dikarenakan semakin banyak data yang digunakan akan semakin baik pula hasil dari analisis yang dilakukan.

Untuk analisis data, terlebih dahulu dilakukan pencarian data yang hilang, setelah melakukan normalisasi data. Pencarian data yang hilang menggunakan metode inversed square distance. Metode pencarian data hilang ini adalah metode yang memperhitungkan nilai jarak dalam menentukan tinggi curah hujan yang dicari. Berikut Persamaan 1 adalah rumus yang digunakan dalam metode inversed square distance.

$$
\mathrm{PX}=\frac{\sum_{i=1}^{n} \frac{P i}{L i}}{\sum_{i=1}^{n} \frac{1}{L i}}
$$

dengan $P x$ adalah curah hujan yang hilang, $P i$ adalah Hujan di stasiun $1,2,3, \ldots$, n. $L i$ adalah jarak antar stasiun 1 , $2,3, \ldots, n$, dan $n$ adalah jumlah stasiun.

Selanjutnya dilakukan uji konsistensi untuk mengetahui apakah data yang digunakan tersebut layak digunakan. Tahapan ini dilakukan setelah mencari data curah hujan yang hilang sehingga dapat terlihat hasil dari pencarian data curah hujan yang hilang tidak mengganggu data curah hujan keseluruhan.

Setelah itu melakukan analisis spektral dengan metode FFT. Tahapan ini adalah tahapan dimana analisis dilakukan dengan metode spektral FFT. Metode ini adalah metode yang dikembangkan dari metode analisis fourier. Dalam menentukan perulangan frekuensi, metode ini dinilai lebih efektif dibanding metode fourier. Berikut Persamaan 2 adalah rumus analisis fourier.

$$
P(f m)=\frac{\Delta t}{2 \sqrt{\pi}} \sum_{n=N / 2}^{n=N / 2} \mathrm{p}\left(\mathrm{t}_{\mathrm{n}}\right): e^{\frac{-2 \cdot \pi \cdot i}{M} \cdot m \cdot n}
$$

dengan $\mathrm{P}(\mathrm{tn})$ adalah data seri curah hujan dalam domain waktu, $\mathrm{P}(\mathrm{fm})$ adalah data dalam domain frekuensi, th 
adalah variabel seri dari waktu yang mempresentasikan panjang data ke $\mathrm{N}$ dan $\mathrm{fm}$ adalah hujan dalam seri frekuensi (frequency domain).

Langkah selanjunya adalah analisis spektral dengan metode lomb periodogram. Yang membedakan metode ini dengan metode yang lain adalah data yang digunakan tidak harus berupa data time series sehingga metode ini juga menghitung time delay dalam perhitungannya. Kelebihan dari metode ini adalah dapat membaca kemungkinan secara lebih detil dibandingkan metode FFT. Berikut Persamaan 3 adalah rumus dari metode lomb periodogram.

$$
P(f)=\frac{1}{4 . \pi \cdot s^{2}}\left\{\frac{\left[\sum_{i=1}^{n}(x-\bar{x}) \cos \omega\left(t_{i}-\tau\right)\right]^{2}}{\sum_{i=1}^{n} \cos ^{2} \omega\left(t_{i}-\tau\right)}+\frac{\left[\sum_{i=1}^{n}(x-\bar{x}) \sin \omega\left(t_{i}-\tau\right)\right]^{2}}{\sum_{i=1}^{n} \sin ^{2} \omega\left(t_{i}-\tau\right)}\right\}
$$

dengan $\mathrm{P}(\mathrm{f})$ adalah periodogram, $\mathrm{x}^{-}$adalah rata-rata tinggi curah hujan, $\mathrm{x}$ adalah tinggi curah hujan, $\mathrm{t}$ adalah waktu dan $\omega$ adalah frekuensi.

Kemudian melakukan analisis korelasi. Dalam metode ini digunakan metode analisis korelasi pearson dalam menghitung korelasi dari data curah hujan sumber data BMKG dan juga data curah hujan TRMM. Hasil dari analisis ini adalah fungsi regresi dan juga nilai korelasi yaitu $\mathrm{R}^{2}$ dengan nilai $0-1$, dengan pengertian bahwa jika hasil korelasi mendekati angka 1 berarti korelasi akan semakin baik. Fungsi dari analisis ini adalah untuk melihat seberapa besar kesamaan nilai dan pola yang dimiliki data hujan BMKG dan TRMM, sehingga dalam melakukan analisis memahami tingkat korelasi antar dua data yang berbeda.

\section{Hasil dan Pembahasan}

\subsection{Perhitungan data curah hujan yang hilang}

Perhitungan data curah hujan yang hilang menggunakan metode inversed square distance yang menggunakan jarak sebagai salah satu variabel perhitungan, sehingga dalam menentukan perhitungan diperlukan jarak antar stasiun hujan. Data curah hujan yang hilang adalah data BMKG, yaitu data BMKG untuk stasiun Fatmawati Soekarno untuk tahun 2015, 2017 dan 2018, dan stasiun hujan Pulau Baai untuk tahun 2017 dan 2018. Sementara data TRMM tidak ada data curah hujan yang hilang. Berikut Tabel 1 adalah jarak antar stasiun hujan di Provinsi Bengkulu.

Tabel 1

Jarak antar stasiun hujan di Provinsi Bengkulu

\begin{tabular}{llll}
\hline Stasiun & Fatmawati S & Pulau Baai & Kepahiyang \\
\hline Fatmawati S & 0 & 8,3 & 37 \\
Pulau Baai & 8,3 & 0 & 45 \\
Kepahiyang & 37 & 45 & 0 \\
\hline
\end{tabular}

Dari nilai jarak yang ada di atas, hasil analisis curah hujan yang hilang dapat ditentukan dengan metode inversed square distance. Dengan menggunakan data stasiun hujan yang terdekat dan juga jarak antar stasiun.

Selanjutnya dilakukan tahap uji konsistensi untuk menentukan data curah hujan yang digunakan tersebut layak atau tidak. Uji dilakukan dengan menjumlahkan curah hujan tahunan sebagai sumbu $x$ dan kumulatif tanpa stasiun hujan tersebut sebagai sumbu $y$. Dari hasil tersebut dibuatlah grafik dan kemudian menentukan nilai korelasi. Nilai korelasi menentukan seberapa besar kelayakan data curah hujan digunakan untuk analisis ini.
Berikut Gambar 2 adalah contoh hasil uji konsistensi yang dilakukan. Uji ini juga digunakan untuk mengetahui apakah pencarian data hujan yang dilakukan dapat mempengaruhi perhitungan dan juga analisis yang dilakukan.

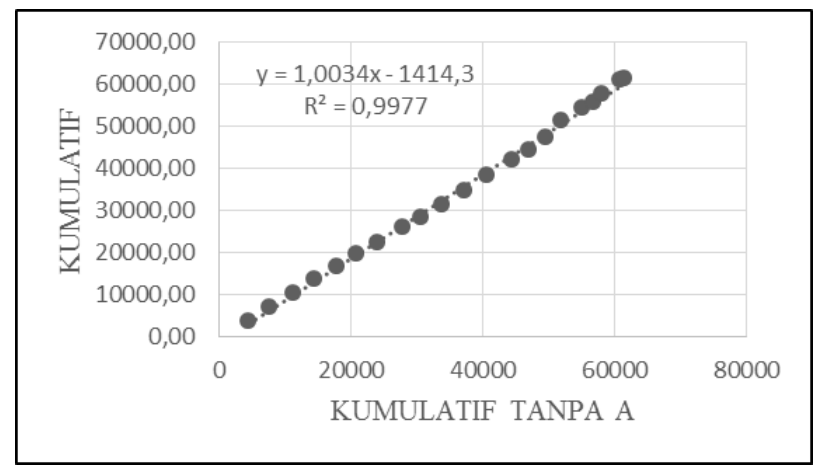

Gambar 2 Hasil uji konsistensi stasiun Fatmawati

Selain hasil uji konsistensi yang dilakukan di stasiun Fatmawati Soekarno, dilakukan juga uji konsistensi di stasiun yang lain dan memiliki nilai yang layak untuk menjadi data yang dianalisis. Berikut Tabel 2 adalah hasil nilai korelasi dari uji konsistensi yang dilakukan di tiga stasiun dan dua sumber data.

Tabel 2

Nilai korelasi uji konsistensi setiap stasiun

\begin{tabular}{llll}
\hline $\begin{array}{l}\text { Stasiun Hujan } \\
\text { BMKG }\end{array}$ & $\mathrm{R}^{2}$ & $\begin{array}{l}\text { Stasiun Hujan } \\
\text { TRMM }\end{array}$ & $\mathrm{R}^{2}$ \\
\hline Fatmawati S & 0,9977 & Fatmawati S & 0,9999 \\
Pulau Baai & 0,9992 & Pulau Baai & 1 \\
Kepahiyang & 0,9988 & Kepahiyang & 0,9997 \\
\hline
\end{tabular}

\subsection{Analisis korelasi data curah hujan BMKG dan TRMM}

Analisis ini dilakukan untuk melihat seberapa besar nilai korelasi atau tingkat kesamaan antar sumber data yang berbeda yaitu BMKG dan TRMM. Analisis ini digunakan untuk memahami kemungkinan bahwa data BMKG dan TRMM mempunyai pola yang sama.

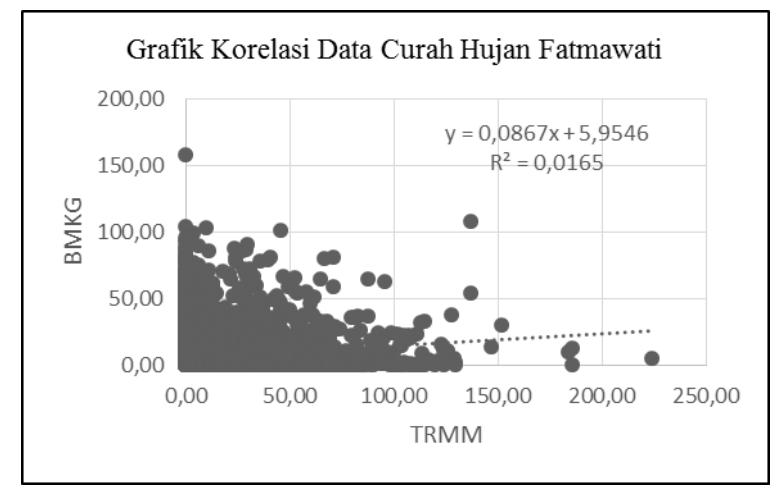

Gambar 3 Contoh hasil analisis korelasi BMKG dan TRMM stasiun Fatmawati

Hasil analisis korelasi menghasilkan nilai korelasi stasiun Fatmawai adalah 0,0165 (Gambar 3), stasiun Pulau Baai 0,0129 dan stasiun Kepahiyang 0,039. 
3.3 Analisis spektrum menggunakan fast fourier transform dan lomb periodogram

Hasil dari analisis menggunakan metode FFT adalah nilai kecepatan sudut yang dikonversi menjadi periode dalam tahun dan nilai amplitudo.

Dari grafik yang dihasilkan dapat terlihat bahwa frekuensi dominan yang punya kemungkinan terpengaruh oleh anomali iklim adalah amplitudo frekuensi dengan periode 2,8 tahun, sesuai dengan kemungkinan pengaruh yang ditimbulkan oleh fenomena alam IODM.

Puncak amplitudo frekuensi yang dominan terpengaruh oleh anomali iklim adalah 2,8 tahun. Membandingkan puncak frekuensi bertujuan untuk menentukan daerah mana yang dominan terpengaruh oleh anomali iklim. Dari dua sumber data yang berbeda, nilai amplitudo yang dihasilkan juga menunjukkan hasil yang berbeda. Berikut Tabel 3 adalah perbandingan frekuensi dominan 2,8 tahun.

Tabel 3

Nilai amplitudo 2,8 tahun tiap stasiun

\begin{tabular}{llll}
\hline \multirow{2}{*}{ Data } & \multicolumn{3}{l}{ Amplitudo 2,8 tahun $\left(\mathrm{mm}^{2}\right)$} \\
\cline { 2 - 4 } & Fatmawati S. & Pulau Baai & Kepahiyang \\
\hline BMKG & 3,4243 & 1,1168 & 4,3456 \\
TRMM & 0,6281 & 0,6281 & 0,1485 \\
\hline
\end{tabular}

Sedangkan untuk metode lomb periodogram memiliki perbedaan cenderung bisa membaca kemungkinan yang tidak bisa terbaca oleh metode lain. Kemampuan membaca kemungkinan perulangan sangat baik. Akan tetapi dalam membaca nilai periode atau perulangan, metode ini kurang baik, sehingga dalam memperkirakan perulangan cenderung memiliki nilai berbeda.

Dari hasil analisis dan grafik yang terbentuk terlihat bahwa nilai amplitudo frekuensi yang dominan adalah dalam periode 3,8 - 4,4 tahun dan kemungkinan anomali iklim yang mempengaruhi curah hujan adalah anomali iklim ENSO atau El Nino dan La Nina.

Puncak frekuensi yang mempunyai kemungkinan terpengaruh oleh anomali iklim berada di 3,8 - 4,4 tahun, sehingga puncak frekuensi yang dibandingkan adalah nilai amplitudo frekuensi yang paling dominan dari kurun waktu perulangan. Berikut Tabel 3 adalah perbandingan puncak frekuensi.

Tabel 3

Perbandingan amplitudo frekuensi dominan BMKG Lomb \& TRMM Lomb

\begin{tabular}{lllll}
\hline \multirow{2}{*}{$\begin{array}{l}\text { Stasiun } \\
\text { BMKG }\end{array}$} & BMKG & \multicolumn{3}{c}{ TRMM } \\
\cline { 2 - 5 } & $\begin{array}{l}\text { Periode } \\
\text { (year) }\end{array}$ & PSD & $\begin{array}{l}\text { Periode } \\
\text { (year) }\end{array}$ & PSD \\
\hline Fatmawati & 4,26 & 4,077 & 3,85 & 0,372 \\
Pulau Baai & 4,33 & 2,436 & 3,85 & 0,372 \\
Kepahiyang & 4,01 & 25,37 & 4,01 & 0,282 \\
\hline
\end{tabular}

Dari Tabel 3 dapat disimpulkan bahwa nilai yang didapatkan dari metode lomb periodogram mempunyai kesimpulan yang sama dengan hasil FFT akan tetapi nilai ampiltudo frekuensi mempunyai nilai yang berbeda. Selain itu, dominan frekuensi memiliki perulangan yang berbedabeda, sehingga dari dua metode tersebut dihasilkan kemungkinan pengaruh anomali iklim yang berbeda.

\subsection{Analisis perkembangan pengaruh perubahan iklim}

Tahapan ini menggunakan metode FFT akan tetapi data yang digunakan hanya dalam waktu 10 tahun saja, lalu maju setiap satu tahun. Tujuan dari analisis ini adalah untuk melihat kecenderungan pertumbuhan dari pengaruh anomali iklim yang terjadi di Propinsi Bengkulu. Hasil analisis menunjukan bahwa setiap stasiun memiliki kecendrungan naik pertumbuhan pengaruhnya kecuali stasiun Fatmawati BMKG, yang cenderung stabil pertumbuhan pengaruhnya.

Selanjutnya adalah melihat kesamaan data stasiun Fatmawati TRMM dan Pulau Baai TRMM. Data yang digunakan dalam analisis ini adalah data BMKG dan TRMM. Data TRMM antara dua stasiun yaitu stasiun Fatmawati dan stasiun Pulau Baai mempunyai kesamaan data curah hujan. Hal itu dapat terjadi dikarenakan stasiun Fatmawati dan stasiun Pulau Baai berada dalam satu bounding box yang sama. Sehingga nilai curah hujan yang digunakan adalah curah hujan rata rata daerah yang masuk dalam area bounding box TRMM. Area bounding box TRMM adalah persegi seluas $16 \mathrm{~km}^{2}$, sedangkan jarak antar stasiun dari stasiun Fatmawati dan stasiun Pulau Baai hanya 3,75 km.

Kemudian menentukan perulangan dari amplitudo frekuensi dominan hasil FFT dan hasil lomb periodogram. Menentukan perulangan yang terpengaruh oleh fenomena anomali iklim adalah dengan melihat frekuensi yang dominan muncul dalam kurun waktu perulangan anomali iklim sesuai literatur. Frekuensi yang ditemukan dari hasil analisis spektral FFT dan lomb periodogram ada beberapa frekuensi yang secara dominan muncul diantara periode periode perulangan anomali iklim.

Dari hasil FFT ditemukan amplitudo frekuensi yang dominan muncul di periode perulangan IODM. Periode perulangan IODM sesuai literatur yang ada berada pada periode 3 - 5 tahun. yang berarti terjadinya pengaruh dari IODM berada di 3 - 5 kali siklus musim tahunan. Dari hasil dari metode FFT dihasilkan periode frekuensi 2,8 tahun, yang dinilai jika sesuai dengan perulangan IODM tidak masuk kedalam periode perulangan IODM, akan tetapi dari hasil FFT juga diketahui bahwa siklus musim tahunan di Propinsi Bengkulu berada pada 0,9 tahun. sehingga tiga kali siklus tahunan adalah dengan periode 2,8 tahun. Jadi dari hasil FFT dapat dinyatakan bahwa perulangan hujan yang terpengaruh IODM berada pada perulangan 2,8 tahun.

Dari lomb periodogram dihasilkan amplitudo frekuensi yang dominan di periode 3,8 - 4,3 tahun. Perulangan anomali yang berada pada periode tersebut adalah anomali iklim ENSO. ENSO memiliki perulangan $4-7$ tahun atau 4 7 kali siklus musim tahunan, dimana siklus musim tahunan di Bengkulu adalah 0,9 sehingga empat kali musim tahunan Propinsi Bengkulu berada pada 3,7 tahun, sehingga amplitudo frekuensi dominan yang dihasilkan pada periode 3,8 - 4,3 tahun masuk didalam kemungkinan terpengaruh oleh ENSO.

Selanjutnya adalah menentukan daerah yang dominan terpengaruh anomali iklim. Dalam menentukan daerah yang terpengaruh oleh anomali iklim digunakan perbandingan amplitudo dari tiap stasiun hujan yang digunakan datanya. Amplitudo yang dibandingkan hanya amplitudo dengan nilai paling tinggi di kurun waktu periode anomali iklim, yaitu periode IODM dan ENSO. Dari hasil analisis dinyatakan bahwa stasiun BMKG yang paling terpengaruh adalah Kepahiyang dan titik daerah TRMM yang paling terpengaruh adalah Fatmawati dan Pulau Baai. Berikut 
Gambar 4 dan Gambar 5 adalah grafik yang menunjukkan perbandingan data.

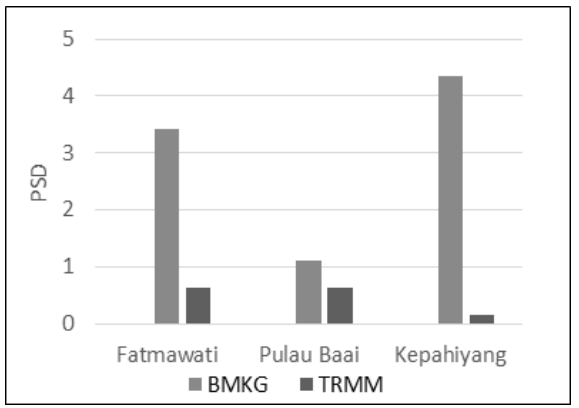

Gambar 4 Perbandingan puncak frekuensi antar stasiun FFT

Terlihat bahwa hasil dari data yang bersumber dari BMKG dan data yang bersumber dari TRMM mempunyai kesimpulan yang berbeda. Korelasi antara dua data sangat kecil sehingga dapat menghasilkan kesimpulan yang berbeda. Kesalahan pembacaan uap air sebagai curah hujan juga kemungkinan berpengaruh terhadap data curah hujan TRMM, sehingga hasil dari analisis berbeda kesimpulan dari tiap sumber data.

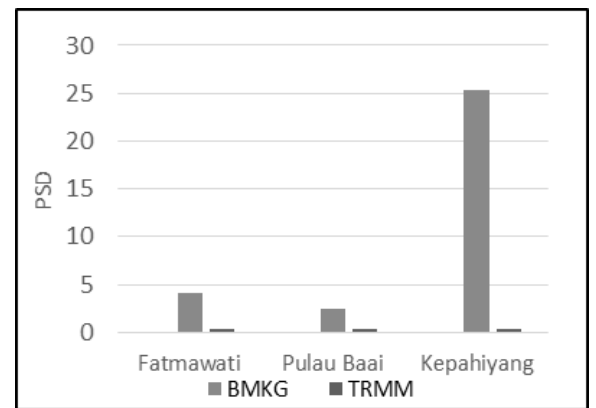

Gambar 5 Perbandingan puncak frekuensi antar stasiun Lomb

Kemudian dilakukan analisis terhadap kecendrungan pertumbuhan pengaruh anomali iklim. Analisis ini menggunakan data tiap 10 tahun lalu maju per tahun, untuk melihat kecendrungan pertumbuhan pengaruh IODM. Dari analisis FFT ditemukan semua stasiun kecuali Fatmawati BMKG punya kecenderungan naik, sedangkan Fatmawati BMKG punya kecendrungan stabil. Dalam menentukan kecendrungan ini, diambil frekuensi dominannya lalu dihasilkanlah grafik dari nilai amplitudo. Untuk mengetahui kecenderungan, maka ditambahkan garis trendline pada grafik. Berikut Gambar 6 dan Gambar 7 adalah contoh grafik hasil analisis 10 tahunan tersebut.

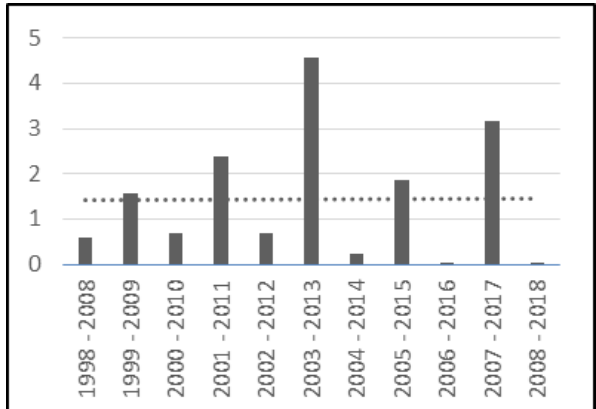

Gambar 6 Grafik pertumbuhan pengaruh anomali iklim Fatmawati BMKG

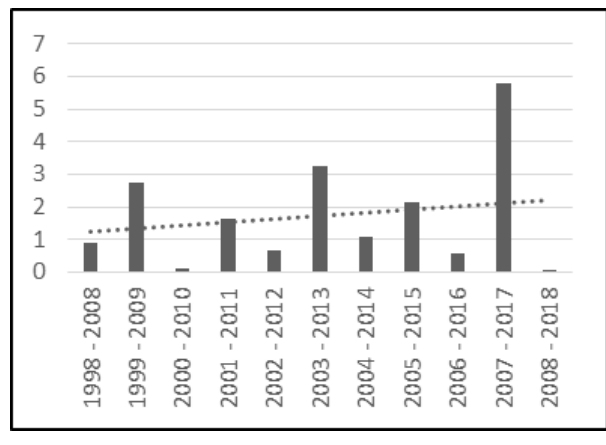

Gambar 7 Grafik pertumbuhan pengaruh anomali iklim Kepahiyang BMKG

\section{Simpulan}

Dengan menggunakan metode FFT disimpulkan bahwa nilai perulangan hujan yang dominan adalah 2,8 tahun. Perulangan ini adalah perulangan hujan yang terpengaruh oleh IODM. Selanjutnya, daerah yang paling terpengaruh oleh perubahan iklim IODM menurut data BMKG adalah stasiun hujan Kepahiyang dengan nilai PSD 4,34 $\mathrm{mm}^{2}$ sedangkan untuk nilai di stasiun Fatmawati serta Pulau Baai adalah $3,42 \mathrm{~mm}^{2}$ dan $1,12 \mathrm{~mm}^{2}$. Sedangkan daerah yang paling terpengaruh oleh perubahan iklim IODM menurut data TRMM adalah stasiun hujan Fatmawati dan Pulau Baai dengan nilai PSD 0,63 $\mathrm{mm}^{2}$ dan nilai untuk stasiun Kepahiyang adalah $0,15 \mathrm{~mm}^{2}$.

Sedangkan dengan menggunakan metode lomb periodogram disimpulkan bahwa nilai perulangan hujan yang dominan adalah 3,8 - 4,4 tahun. Perulangan ini adalah perulangan hujan yang terpengaruh El Nino dan La Nina. Untuk daerah yang paling terpengaruh oleh perubahan iklim El Nino dan La Nina menurut data BMKG adalah stasiun hujan Kepahiyang dengan nilai PSD 25,37 $\mathrm{mm}^{2}$ dan untuk nilai di stasiun Fatmawati serta Pulau Baai adalah $4,08 \mathrm{~mm}^{2}$ dan $2,44 \mathrm{~mm}^{2}$. Selanjutnya daerah yang paling terpengaruh oleh perubahan iklim El Nino dan La Nina menurut data TRMM adalah stasiun hujan Fatmawati dan Pulau Baai dengan nilai $0,37 \mathrm{~mm}^{2}$ dan untuk nilai di stasiun Kepahiyang adalah $0,28 \mathrm{~mm}^{2}$.

Dari analisis tiap 10 tahun disimpulkan bahwa pengaruh perubahan iklim stasiun Fatmawati BMKG punya kencendrungan stabil sedangkan di stasiun Pulau Baai dan Kepahiyang BMKG memiliki kencendrungan naik. Untuk data yang bersumber dari TRMM semua stasiun mempunyai kencendrungan naik.

\section{Daftar Pustaka}

[1] Mulyana, E.: Hubungan antara enso dengan variasi curah hujan di Indonesia. Jurnal Sains \& Teknologi Modifikasi Cuaca, 3(1):1, 2000

[2] Soubeyran, R.: An overview of the roots of civil wars: natural factors and economic conditions. G-MonD Policy Papers, 1 (January), 2013, 1-32

[3] Noya, V.H.P., Rumlawang, F.Y., Lesnussa, Y.A.: Aplikasi transformasi fourier untuk menentukan periode curah hujan (studi kasus: periode curah hujan di Kabupaten Seram Bagian Barat, Provinsi Maluku), Jurnal Matematika Integratif 10(2), 2014, 85-94 